Columbia Law School

Scholarship Archive

\title{
A Turquoise Mess: Green Subsidies, Blue Industrial Policy and Renewable Energy: The Case for Redrafting the Subsidies Agreement of the WTO
}

\author{
Aaron Cosbey \\ International Institute for Sustainable Development (IISD), acosbey@iisd.ca \\ Petros C. Mavroidis \\ Columbia Law School, petros.mavroidis@unine.ch
}

Follow this and additional works at: https://scholarship.law.columbia.edu/faculty_scholarship

Part of the Energy and Utilities Law Commons, Environmental Law Commons, International Trade Law Commons, and the Law and Economics Commons

\section{Recommended Citation}

Aaron Cosbey \& Petros C. Mavroidis, A Turquoise Mess: Green Subsidies, Blue Industrial Policy and Renewable Energy: The Case for Redrafting the Subsidies Agreement of the WTO, EUROPEAN UNIVERSITY institute, Robert Schuman Centre for Advanced Studies, Global Governance Programme Policy Paper No. RSCAS 2014/17; COLUMBIA UNIVERSITY SCHOOL OF LAW, THE CENTER FOR LAW \& ECONOMIC STUDIES WORKING PAPER No. 473 (2014).

Available at: https://scholarship.law.columbia.edu/faculty_scholarship/2374

This Working Paper is brought to you for free and open access by the Faculty Publications at Scholarship Archive. It has been accepted for inclusion in Faculty Scholarship by an authorized administrator of Scholarship Archive. For more information, please contact scholarshiparchive@law.columbia.edu. 


\title{
The Center for Law and Economic Studies \\ Columbia University School of Law \\ 435 West $116^{\text {th }}$ Street \\ New York, NY 10027-7201
}

(212) 854-3739

\section{A Turquoise Mess: \\ Green Subsidies, Blue Industrial Policy and Renewable Energy: The Case for Redrafting the Subsidies Agreement of the WTO}

\author{
Aaron Cosbey \\ International Institute for Sustainable Development \\ Petros C. Mavroidis \\ Columbia Law School
}

Working Paper No. 473

February 1, 2014

Do not quote or cite without author's permission.

An index to the working papers in the Columbia Law

School Working Paper Series is located at

http://web.law.columbia.edu/law-economic-studies/working-papers 

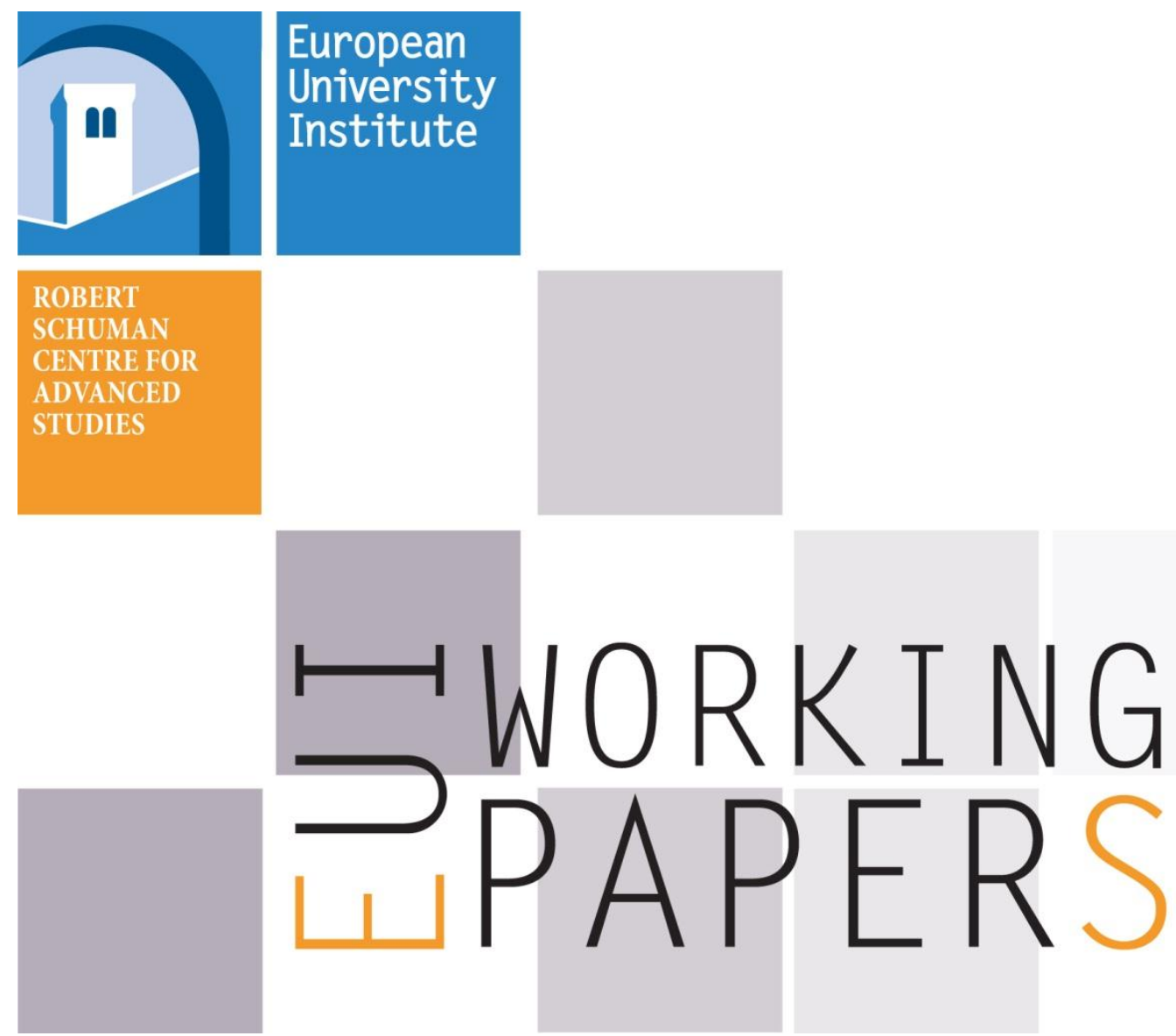

RSCAS 2014/17

Robert Schuman Centre for Advanced Studies Global Governance Programme-82

A Turquoise Mess: Green Subsidies, Blue Industrial Policy and Renewable Energy: the Case for Redrafting the Subsidies Agreement of the WTO

Aaron Cosbey and Petros C. Mavroidis 
European University Institute

Robert Schuman Centre for Advanced Studies

Global Governance Programme

A Turquoise Mess: Green Subsidies, Blue Industrial Policy and Renewable Energy: the Case for Redrafting the Subsidies Agreement of the WTO

Aaron Cosbey and Petros C. Mavroidis

EUI Working Paper RSCAS 2014/17 
This text may be downloaded only for personal research purposes. Additional reproduction for other purposes, whether in hard copies or electronically, requires the consent of the author(s), editor(s). If cited or quoted, reference should be made to the full name of the author(s), editor(s), the title, the working paper, or other series, the year and the publisher.

ISSN 1028-3625

(C) Aaron Cosbey and Petros C. Mavroidis, 2014

Printed in Italy, February 2014

European University Institute

Badia Fiesolana

I - 50014 San Domenico di Fiesole (FI)

Italy

www.eui.eu/RSCAS/Publications/

www.eui.eu

cadmus.eui.eu 


\section{Robert Schuman Centre for Advanced Studies}

The Robert Schuman Centre for Advanced Studies (RSCAS), created in 1992 and directed by Brigid Laffan since September 2013, aims to develop inter-disciplinary and comparative research and to promote work on the major issues facing the process of integration and European society.

The Centre is home to a large post-doctoral programme and hosts major research programmes and projects, and a range of working groups and ad hoc initiatives. The research agenda is organised around a set of core themes and is continuously evolving, reflecting the changing agenda of European integration and the expanding membership of the European Union.

Details of the research of the Centre can be found on:

http://www.eui.eu/RSCAS/Research/

Research publications take the form of Working Papers, Policy Papers, Distinguished Lectures and books. Most of these are also available on the RSCAS website:

http://www.eui.eu/RSCAS/Publications/

The EUI and the RSCAS are not responsible for the opinion expressed by the author(s).

\section{The Global Governance Programme at the EUI}

The Global Governance Programme (GGP) is research turned into action. It provides a European setting to conduct research at the highest level and promote synergies between the worlds of research and policy-making, to generate ideas and identify creative and innovative solutions to global challenges.

The GGP comprises three core dimensions: research, policy and training. Diverse global governance issues are investigated in research strands and projects coordinated by senior scholars, both from the EUI and from other internationally recognized top institutions. The policy dimension is developed throughout the programme, but is highlighted in the GGP High-Level Policy Seminars, which bring together policy-makers and academics at the highest level to discuss issues of current global importance.The Academy of Global Governance (AGG) is a unique executive training programme where theory and "real world" experience meet. Young executives, policy makers, diplomats, officials, private sector professionals and junior academics, have the opportunity to meet, share views and debate with leading academics, top-level officials, heads of international organisations and senior executives, on topical issues relating to governance.

For more information:

http://globalgovernanceprogramme.eui.eu 


\begin{abstract}
Canada-Renewable Energy presented the WTO Panel and Appellate Body (AB) with a novel issue: at the heart of the dispute was a measure adopted by the province of Ontario whereby producers of renewable energy would be paid a premium relative to conventional power producers. Some WTO Members complained that the measure was a prohibited subsidy because payments were conditional upon using Canadian equipment for the production of renewable energy. The $\mathrm{AB}$ gave them right only in part: it found that a local content requirement had indeed been imposed, but also found that it lacked evidence to determine whether a subsidy had been bestowed. The report is, for the reasons explained below, incoherent and could hardly serve as precedent for resolution of similar conflicts in the future. The facts of the case though, do raise legitimate questions both with respect to the specifics of the case, as well as of more general nature regarding the WTO Agreement on Subsidies and Countervailing Measures (SCM Agreement), and the role of the judge when facing legislative failure. In this paper, we provide some responses to these questions in light of the theory and evidence regarding industrial policy in the name of environmental protection.
\end{abstract}

\title{
Keywords
}

WTO; subsidies; renewable energy.

JEL Classification: F18, K32 


\section{The Issue}

In this paper we discuss the Panel and AB reports on Canada-Renewable Energy. ${ }^{1}$ In that case WTO Members challenged the consistency of a measure by the Canadian Province of Ontario (to subsidize the production of renewable energy) with the rules of the WTO. The WTO adjudicating bodies gave right to the complainants, albeit without upholding every claim presented to them.

The reader of the reports is left with the impression that the WTO adjudicating bodies felt that it was necessary to engage in legal acrobatics in order to avoid finding that a scheme aimed at promoting a public good - the underlying feed-in tariff for renewable energy - was in fact a subsidy. There are many problems with the approach followed: it is hardly reconcilable with the text and the spirit of the relevant WTO rules; it might be giving WTO Members the wrong incentives by opening the door wide to industrial policy unlimited; it places squarely before us the question whether the WTO courts have behaved as agents called to apply a law decided by their principals, or whether they re-invented themselves as principals and decided what the law should be.

And yet, the WTO adjudicating bodies fought a fight worth fighting for, and at the very least sensitized us all to the apple in the picture: the rationale for subsidization should matter, and the current multilateral framework, the Agreement on Subsidies and Countervailing Measures, must be rethought in this respect.

The argument that we advance in this paper is that the WTO SCM Agreement must be redrafted so as to account for the rationale of subsidies: markets work well for ice-creams and not so well for clean air, as the commonplace saying goes. The SCM Agreement needs to acknowledge as much, especially since subsidies are often less distorting than other instruments of policy intervention aiming to bring about public goods, such as clean air. It is not for WTO adjudicating bodies to fix the current problem area, it is for the WTO Membership to stand up and respond to the call of duty.

The rest of the paper is divided as follows: in Section 2, we detail the facts of the dispute, the claims of the complainants, and the decision by the Panel and the AB, and in Section 3 we express our critique of the approach followed; in Section 4, we ask the question how else could the AB have addressed the question asked within the four corners of the SCM Agreement, and we conclude that the SCM Agreement as currently drafted does not leave much leeway to adopt similar measures (in contrast, the original SCM Agreement, e.g. before Art. 8 was rescinded, allowed for some breathing space in this respect).

Alas, the environmental community cannot rely on the $\mathrm{AB}$ repeating its acrobatics either because, as we will show, there are a series of problems inherent in the 'methodology' it adopted to address the issue that make it difficult to repeat it. ${ }^{2}$ It is this observation that brings us to the question whether a redraft of the SCM Agreement might be necessary. To do that we have a detour in economic theory,

Aaron Cosbey \& Petros C. Mavroidis: Associate and Senior Advisor, International Institute for Sustainable Development, and Edwin B. Parker Professor of Law at Columbia Law School (on leave at European University Institute, Florence), respectively. We would like to thank Caroline Fisher, Henrik Horn, Andrea Mastromatteo, Luca Rubini, and Terry Stewart for comments on previous drafts and numerous discussions on the issue.

1 Two separate disputes (Canada-Certain Measures Affecting the Renewable Energy Generating Sector (DS 412); Canada-Measures Relating to the Feed-In Tariff Program (DS 426), hereinafter jointly referred to as Canada-Renewable Energy) gave rise to two Panels, but at the end a joint report was drafted. Salzman and Wu (2014) provide an excellent overview of the dispute.

2 Significantly, because the $\mathrm{AB}$ did not rule that the measure was not a subsidy. Instead the three members of the $\mathrm{AB}$ Division in charge of this dispute energetically avoided making any determination; they also laid out the conditions they would need to have before their eyes in order to determine a benefit, so the real question is what happens next time, when those conditions have been met by the complainants? Here we need to ask whether the $\mathrm{AB}$ would find the measure not a subsidy because of is object or its intent, a key question, and there are hints in in the text that suggest both directions. 
and we ask in Section 5 whether and if so, how the rationale for subsidization matters to make the point that lumping all subsidies together in one basket irrespective of their rationale (as the current SCM Agreement does) is wrong. We distil our main conclusions and propose a re-write of the SCM Agreement in this respect in Section 6, whereas in Section 7 we recap the key points we have made in this paper.

\section{Facts and Decision}

\section{II.A. The Facts}

In Canada-Renewable Energy, complainants challenged measures that had been adopted by the Province of Ontario (Canada) aiming at promoting the consumption of renewable energy. Ontario Power Authority (OPA) was providing a financial contribution to producers of wind-power and solar photovoltaic (PV) energy: it offered a guaranteed rate for electricity over a specified period (20 to 40 years) at rates set above those accorded to conventional producers of power. Such payments, over 90 schemes of which exist globally, are commonly known as feed-in tariffs (FITs), and in Ontario they aimed at delivery of energy from renewables into the grid both from commercial producers of energy, as well as from individual home owners. ${ }^{3}$

To this effect, the Province of Ontario would enter into contractual arrangements with producers of solar and wind energy (FIT, and microFIT contracts) and compensate them by paying them a fixed price per unit of production. This is how the Panel report describes the measures: ${ }^{4}$

\section{'The FIT Programme}

The FIT Programme has very clearly two fundamental objectives: First, to encourage the participation of new generation facilities using renewable sources of energy into Ontario's electricity system in order to diversify Ontario's supply-mix and help replace the generation capacity that has been (and will be) lost as a result of the closure of Ontario's coal-fired facilities by 2014, and thereby also reduce greenhouse gas emissions; and secondly, to stimulate local investment in the production of renewable energy generation equipment needed to design and construct qualifying generation facilities using solar $\mathrm{PV}$ and windpower technologies. These objectives are pursued through the execution of the FIT and microFIT Contracts, which involve an exchange of performance obligations on the part of the OPA and qualifying Suppliers. There is no inherent grant element to the FIT and microFIT transactions.

\section{The FIT and microFIT Contracts}

In essence, the FIT and microFIT Contracts envisage an exchange of the following core performance obligations between Suppliers and the OPA:
A Supplier must:
i. design, construct, own (or lease) and operate a qualifying facility in accordance with all relevant IESO Market Rules, laws and regulations;
ii. comply with the "Minimum Required Domestic Content Level" when designing and constructing a solar PV or a microFIT windpower facility;
iii. deliver the electricity that is produced into the Ontario electricity system in accordance with all relevant IESO Market Rules, laws and regulations;
iv. participate in a defined electricity payment processes to settle Contract Payments that is not unlike that used generally in Ontario's electricity system; and

\footnotetext{
The contribution was tied to the use of local machinery (local content requirement), a point that we discuss below.

4 WTO Panel Report, Canada - Certain Measures Affecting the Renewable Energy Generation Sector; Canada Measures Relating to the Feed-In Tariff Program (Canada - Renewable Energy), WT/DS412/R; WT/DS426/R, adopted 19 December 2012, paras. 7.216-19.
} 
v. assign all Environmental Attributes associated with the Contract Facility to the OPA, pay the OPA $50 \%$ of all payments received by the Supplier under the "ecoENERGY for Renewable Power Program", and effectively transfer to the OPA $80 \%$ of total net revenues from the sale of Future Contract Related Products.

In return, the OPA agrees to make the Contract Payments, which are defined in such a way that ensures each Supplier will be remunerated via defined settlement processes at the guaranteed FIT Contract Price for each kWh of Delivered Electricity for 20 years.'

In its report, the $\mathrm{AB}$ provided its own understanding of the challenged measure in the following terms: ${ }^{5}$

'An entity that enters into a FIT or microFIT Contract is required to, inter alia, build, operate, and maintain the approved generation facility in accordance with all relevant laws and regulations, and deliver the electricity produced into the Ontario electricity system. In return for performing these and other contractual obligations, such entity will be remunerated, over the term of the particular contract, in accordance with a formula that is based on a standard "Contract Price established by the OPA.

In addition to these obligations, the FIT Programme imposes "Minimum Required Domestic Content Levels" that must be satisfied in the development and construction of solar PV electricity generation facilities participating in both streams of the FIT Programme and of windpower electricity generation facilities taking part in the FIT stream. The Minimum Required Domestic Content Levels do not apply to qualifying projects using any of the other renewable energy sources covered by the FIT Programme. The applicable Minimum Required Domestic Content Levels prescribed under both streams of the FIT Programme are summarized in Table 1 at paragraph 1.4 of these Reports.' (italics in the original)

There is thus no doubt that a fixed rate was paid conditional on the use of local content machinery producing renewable energy.

\section{II.B. The Legal Complaints}

Complainants (Japan, EU) challenged the consistency of the Canadian measure under the Uruguay Round General Agreement on Tariffs and Trade (GATT), ${ }^{6}$ the Uruguay Round Agreement on TradeRelated Investment Measures (TRIMS Agreement), ${ }^{7}$ as well as the Uruguay Round Agreement on Subsidies and Countervailing Measures (SCM Agreement). ${ }^{8}$ In a nutshell, complainants claimed: (a) that the measure was inconsistent with Art. III.4 GATT, and Art. 2.1 TRIMs, because it was a traderelated investment measure, and the attached requirement to use Canadian equipment to produce renewable energy was a local content requirement, and thus, inconsistent with this provision; (b) that since a financial contribution by the government was taking place in order to compensate users of Canadian equipment, a subsidy was being granted the payment of which was conditional upon fulfilling a local content requirement: consequently, the measure as a prohibited subsidy as per Art. 3 SCM Agreement.

\footnotetext{
Ibid, paras. 4.20-21.

6 World Trade Organization (1999), The Legal Texts: The Results of the Uruguay Round of Multilateral Trade Negotiations. Cambridge: Cambridge University Press, 17.

7 Ibid, 143.

$8 \quad$ Ibid, 231.
} 


\section{II.C. The Decision by the AB}

\section{II.C.1. The Claim under GATT/TRIMs}

The Panel had no trouble reaching the conclusion that the Canadian measures (the FIT and microFIT programs) were trade-related investment measures, and that to obtain the advantage of the programs it was necessary to comply with a local content requirement. It thus found - in an aspect of the ruling that was not appealed - that the measures were inconsistent with Art. III.4 GATT, and Art. 2.1 TRIMs. Local content requirements of this type are proscribed in the Illustrative List of trade related investment measures cited in Art. 2.2 TRIMs.

So far, so good: Canada however, anticipating this outcome, had argued that the measure was government procurement: the Province of Ontario (through the Ontario Power Authority) was procuring renewable energy from individuals producing it. Canada thus invoked Art. III.8 GATT as grounds justifying violations of national treatment. Recall that, under the terms of this provision, WTO Members can deviate from their obligation to afford national treatment to imported goods (e.g. by abolishing, inter alia, local content requirements), if their practices qualify as subsidy or as government procurement: had the Canadian claim been accepted, its local content requirement would have been exonerated; complainants would then have to argue (assuming they were willing to pursue the case further) that the Canadian measure was in violation of Canada's obligations under the Uruguay Round Government Procurement Agreement (GPA). ${ }^{9}$ To do this, nevertheless, they would need to raise a new request for consultations, e.g. start another dispute anew.

Canada was arguing that Art. III.8 GATT could serve as exception for violations of the TRIMs Agreement as well, and not only for violations of the GATT. This was necessary, since the Panel had found that the Canadian measure was in violation of Art. 2.1 TRIMs. The complainants took the opposite view.

The Panel first delineated the scope of the exemption provided by Art. III.8 GATT. To this effect, it held that Art. III.8 GATT could indeed serve as grounds to justify deviations from the obligations assumed not only under the GATT, but also under the TRIMs Agreement as well.

'The Panel reasoned that "any government procurement transactions covered by the terms of Article III:8(a) of the GATT 1994 will be removed from the scope of the obligations set out in Article III, including Article III:4" and "where a particular TRIM involves the same kind of government procurement transactions described in Article III:8(a), it cannot be found to be inconsistent with the obligation in Article 2.1 of the TRIMs Agreement., ${ }^{10}$

In $\$ 5.33$ of its report, the $\mathrm{AB}$ provided its explicit support for this understanding of the relationship between the GATT and the TRIMs Agreement:

'For the reasons stated above, we consider that the Panel correctly rejected the European Union's argument that Article III:8(a) of the GATT 1994 is not applicable to measures that fall within the scope of Article 2.2 of the TRIMs Agreement and the Illustrative List annexed thereto. Therefore, we uphold the Panel's finding, in paragraph 7.121 of the Panel Reports, that "Paragraph 1(a) of the Illustrative List in the Annex to the TRIMs Agreement d[id] not obviate the need for [the Panel] to undertake an analysis of whether the challenged measures are outside of the scope of application of Article III:4 of the GATT 1994 by virtue of the operation of Article III:8(a) of the GATT 1994."'

$9 \quad$ Ibid, 383.

10 WTO Appellate Body Report, Canada - Certain Measures Affecting the Renewable Energy Generation Sector; Canada - Measures Relating to the Feed-In Tariff Program (Canada - Renewable Energy), WT/DS412/AB/R; WT/DS426/AB/R, adopted 6 May 2013, para 5.10. 
The $\mathrm{AB}$ then moved to provide the substantive test for successfully invoking this provision (Art. III.8 GATT); it held that the following conditions must be cumulatively met (\$5.74):

'We consider that Article III:8(a) sets out a derogation from the national treatment obligation contained in Article III of the GATT 1994. The provision exempts from the national treatment obligation certain measures containing rules for the process by which government purchases products. Under Article III:8(a), the entity procuring products for the government is a "governmental agency". We have found above that a "governmental agency" is an entity performing functions of government and acting for or on behalf of government. Furthermore, we have found that the derogation of Article III:8(a) must be understood in relation to the obligations stipulated in Article III. This means that the product of foreign origin must be in a competitive relationship with the product purchased. Furthermore, Article III:8(a) is limited to products purchased for the use of government, consumed by government, or provided by government to recipients in the discharge of its public functions. On the contrary, Article III:8(a) does not cover purchases made by governmental agencies with a view to reselling the purchased products in an arm's-length sale and it does not cover purchases made with a view to using the product previously purchased in the production of goods for sale at arm's length.'

In particular, the WTO Member invoking it would have to show that:

(a) The purchased products by a government agency were intended to be directed at the government, or be used for government purposes $(\$ 5.68) ;{ }^{11}$ and

(b) That the government did not purchase goods with the intent to resell them commercially (\$5.69).

In other words (\$5.69):

'Purchase that does not fulfill the requirement of being made "for governmental purposes" will not be covered by Article III:8(a) regardless of whether it complies with the requirement of being made "not with a view to commercial resale". These are cumulative requirements. We therefore disagree with the Panel's proposition that where a government purchase of goods is made "with a view to commercial resale", it is for that reason also not a purchase "for governmental purposes".'

Finally, 'commercial resale' should not be equated to 'for profit resale'. What matters is that a resale is done at arm's length. The $\mathrm{AB}$ noted though, that, under assumptions, even transactions aiming at cutting losses could be rational business decisions, and thus, at arm's length. The adjudicator, in the AB's view, when performing this test should be reviewing the transaction both from the buyer's as well as the seller's perspective $(\S 5.71):^{12}$

'We see profit-orientation generally as an indication that a resale is at arm's length. Profitorientation indicates that the seller is acting in a self-interested manner. Yet, as the Panel noted, there are circumstances where a seller enters into a transaction out of his or her own interest without making a profit. There are different circumstances in which a seller may offer a product at a price that does not allow him or her to make a profit, or sometimes even fully to recoup cost. In such circumstances, it may be useful to look at the seller's long-term strategy. This is because lossmaking sales could not be sustained indefinitely and a rational seller would be expected to be profit-oriented in the long term, though we accept that strategies can vary widely and thus do not see this as applying axiomatically. The transaction must also be assessed from the perspective of the buyer. A commercial resale would be one in which the buyer seeks to maximize his or her own interest. It is an assessment of the relationship between the seller and the buyer in the transaction in question that allows a judgement to be made whether a transaction is made at arm's length.'

When applying this test to the specifics of the case, the $A B$ underscored that this provision could be justifiably invoked only if the challenged measure concerned two goods that were in competitive

11 The $\mathrm{AB}$ explained in the same paragraph, that a 'rational relationship between the products and government purposes must exist.

12 The AB seems to suggest, without saying so explicitly, that selling not at arm's length would not remove a measure from the ambit of the exemption granted through Art. III.8 GATT. 
relationship with each other (§5.63). In this case however, the government was purchasing electricity, whereas the foreign product that was allegedly being treated worse than its domestic counterpart was generation equipment; the $\mathrm{AB}$ noted that electricity and generation equipment are not in competitive relationship with each other ( $\$ 5.75 f f$.$) . The Panel had made the same point as well, but had added$ that generation equipment was being used in order to produce electricity, and because of the 'close relationship' of the two, Art. III.8 GATT was applicable (§5.76). The AB disagreed (§5.79):

'In the case before us, the product being procured is electricity, whereas the product discriminated against for reason of its origin is generation equipment. These two products are not in a competitive relationship. None of the participants has suggested otherwise, much less offered evidence to substantiate such proposition. Accordingly, the discrimination relating to generation equipment contained in the FIT Programme and Contracts is not covered by the derogation of Article III:8(a) of the GATT 1994. We therefore reverse the Panel's findings.'

The violation of Art. 2.1 TRIMs (and Art. III.4 GATT) as a result, stood.

\section{II.C.2. The Claim under the SCM Agreement}

For a measure to constitute a subsidy, it must, as per Arts. 1 and 2 SCM Agreement, cumulatively satisfy three conditions: (a) a financial contribution by the government must (b) confer a benefit (c) to a specific recipient.

Financial contribution: The forms of financial contribution are detailed in Art. 1 SCM Agreement. The Panel had found that the Canadian measure was a purchase of goods, one of the forms mentioned in the body of Art. 1 SCM Agreement ( $\$ 5.110-113$ of the AB report):

'The Panel's reasoning in reaching this conclusion was based on three key elements. First, it noted that the OPA transfers funds to FIT suppliers for "delivered electricity" into Ontario's electricity grid. It is by paying a FIT Contract Price for delivered electricity that the Government of Ontario seeks to achieve the objective of securing investment in new generation facilities for the purposes of diversifying Ontario's supply-mix. Thus, in the Panel's view, there is no grant element inherent in the design and operation of the FIT Programme. The Panel highlighted that, while FIT and microFIT Contracts facilitate suppliers' search for project financing, it would be wrong to characterize the Contract Payments themselves as finance payments for the construction of a generation facility.

Second, the Panel found that the Government of Ontario takes possession over electricity and thus "purchases electricity". The Panel found that government "purchases [of] goods" will arise under the terms of Article 1.1(a)(1)(iii) of the SCM Agreement when a "government" or "public body" obtains possession (including in the form of an entitlement) over a good by making a payment of some kind (monetary or otherwise). In particular, given the specific characteristics of electricity, the Panel preferred to characterize a purchase of electricity as involving the transfer of an entitlement to electricity, rather than the taking of physical possession of the electricity. Moreover, the Panel rejected the European Union's argument that the notion of government "purchases [of] goods" implies that the government is the entity being supplied with something for its use.

The Panel then observed that government "purchases [of] goods" require the involvement of the "government" or a "public body". In the Panel's view, this is exactly what happens through the FIT Programme and Contracts, where the combined actions of all three "public bodies" involved (i.e. the OPA, Hydro One Inc., and the IESO) demonstrate that the Government of Ontario purchases electricity within the meaning of Article 1.1(a)(1)(iii) of the SCM Agreement.

Third, the Panel found that the legislative and regulatory framework of the FIT Programme and Contracts supports the conclusion that the challenged measures are perceived by the Government of Ontario and by others in Ontario as governmental activity that involves the procurement or purchase of electricity.' (emphasis in the original)

The AB upheld these findings ( $\$ 5.128)$. 
Benefit: this is where the crux of the analysis by both the Panel and the AB took place. The Panel (\$§7.243ff.) had found that the measure could not have been equated to a subsidy because, on the evidence provided, the Panel could not establish whether a benefit had indeed been bestowed. The Panel held that it did not possess enough information to decide whether this had been the case: for a finding that a benefit had been bestowed, a comparison between the rate of return provided to the generators benefiting from the FIT and the average cost of capital for business of comparable risk profile was warranted $;{ }^{13}$ as the Panel did not possess information on this score, it could not decide this issue. In $§ 7.322$, we read:

'Thus, one way to determine whether the challenged measures confer a benefit within the meaning of Article 1.1(b) of the SCM Agreement would involve testing them against the types of arm's length purchase transactions that would exist in a wholesale electricity market whose broad parameters are defined by the Government of Ontario. In the present set of circumstances, this could be done by comparing the terms and conditions of the challenged FIT and microFIT Contracts with the terms and conditions that would be offered by commercial distributors of electricity acting under a government-imposed obligation to acquire electricity from generators operating solar PV and wind power plants of a comparable scale to those functioning under the FIT Programme.'

One member of the Panel issued a dissenting opinion, holding that a benefit had indeed been conferred, since on Canada's own admission producers of solar energy would not be in the market in the first place absent the Canadian measure ( $\$ 9.11 \mathrm{ff}$.).

The $\mathrm{AB}$ was thus confronted with a majority opinion that left the matter un-decided (in the absence of adequate evidence), and a minority opinion to the effect that a benefit had indeed been bestowed. ${ }^{14}$

The AB first defined the relevant product market, a necessary pre-condition in its view in order to decide whether a benefit had been bestowed to specific recipients. It held that two separate markets existed, namely, a market for conventional-, and a market for renewable energy ( $\$ 5.176 \mathrm{ff}$.); in doing that, it distanced itself from the Panel, since, in its view, supply side- substitutability mattered for the definition of the relevant product market (\$\$5.171-172). That is, as well as considering the substitutability of conventional and renewable energy from the perspective of consumers of that energy (i.e., demand-side analysis, where the $\mathrm{AB}$ agreed that there is a high degree of substitutability $(\$ 5.170))$, the $\mathrm{AB}$ argued that it also mattered how substitutable the two goods were from the producer's perspective. In making this argument the $\mathrm{AB}$ cited as precedent EC and Certain Member States - Large Civil Aircraft where, in addressing market definition for the purposes of Articles 6(3)(a) and 6(3)(b) of the SCM Agreement, the AB had found:

'Demand-side substitutability - that is, when two products are considered substitutable by consumers - is an indispensable, but not the only relevant, criterion to consider when assessing whether two products are in a single market. Rather, a consideration of substitutability on the supply-side may also be required. For example, evidence on whether a supplier can switch its production at limited or prohibitive cost from one product to another in a short period of time may also inform the question of whether two products are in a single market. ${ }^{15}$

13 They did not say that this was necessary; rather they said that this was one way in which a proper benchmark could have been established. They did not rule out, however, the use of other methods (other than those that had been offered by the complainants, all of which they rejected), see Panel report at $\$ 7.322$. It is worth noting that putting such a test into practice would be challenging to say the least; how to identify a sector with a "comparable risk profile," and how to accurately estimate the cost of capital facing this sector?

14 The member expressing the minority opinion did not explicitly ask the question whether the subsidy was specific as well. Since local content subsidies are prohibited, and since all prohibited subsidies are specific, this question need not be asked anyway, though.

15 WTO Appellate Body Report, European Communities - Measures Affecting Trade in Large Civil Aircraft (EC and Certain Member States - Large Civil Aircraft), WT/DS316/AB/R, adopted 18 May 2011, para 1121. Cited at §5.171. 
The $\mathrm{AB}$ found that in the present case there were supply-side factors that argued in favour of considering renewable energy as a different market from conventionally produced energy. Specifically, renewable energy producers cannot compete with conventional producers; this is a result of their different cost structures and operating costs (very high upfront capital costs, very low operating costs) and characteristics (intermittency of supply means such power is unsuitable for baseload and peak-load generation). (\$5.174)

These considerations mean that, where there is straight competition between conventional and renewable energy producers, "markets for wind- and solar PV-generated electricity can only come into existence as a matter of government regulation." (\$5.175) Whether that regulation comes in the form of a FIT or in the form of a mandated obligation for utilities to purchase some quantity of electricity from renewable sources, this amounts to a regulatory creation of a new market, through a determination of the supply mix. Importantly, at this point the $A B$ warns that, for either type of measure, "the definition of a certain supply-mix by the government cannot in and of itself be considered as conferring a benefit within the meaning of Article 1.1(b) of the SCM Agreement." (Ibid; emphasis in the original).

As this warning presages, the resulting finding - that the relevant market for the purposes of determining a benefit is not the competitive wholesale market, but rather the competitive markets for wind- and solar PV-generated electricity - is the cornerstone of the AB's disagreement with the Panel, and lies at the heart of the AB's inability to find that the measure at hand is a subsidy.

With the market now defined, the next logical question was whether a benefit had been bestowed on producers of renewable energy. Two paragraphs of the $\mathrm{AB}$ report are important in this context. First, §5.185:

'Nevertheless, while introducing legitimate policy considerations into the determination of benefit cannot be reconciled with Article 1.1(b) of the SCM Agreement, we do not think that a marketbased approach to benefit benchmarks excludes taking into account situations where governments intervene to create markets that would otherwise not exist. For example, governments create electricity markets with constant and reliable supply. By regulating the quantity and the type of electricity that is supplied through the network (base-load, intermediate-load, or peak-load) and the timing of such supply, governments ensure that there is a continuous supply-demand balance between generators and consumers, thus avoiding imbalances that would destabilize the network and cause interruptions of power supply. Although this type of intervention has an effect on market prices, as opposed to a situation where prices are determined by unconstrained forces of supply and demand, it does not exclude per se treating the resulting prices as market prices for the purposes of a benefit analysis under Article 1.1(b) of the SCM Agreement. In fact, in the absence of such government intervention, there could not be a market with a constant and reliable supply of electricity.'

Then, §5.188:

'Nevertheless, a distinction should be drawn between, on the one hand, government interventions that create markets that would otherwise not exist and, on the other hand, other types of government interventions in support of certain players in markets that already exist, or to correct market distortions therein. Where a government creates a market, it cannot be said that the government intervention distorts the market, as there would not be a market if the government had not created it. While the creation of markets by a government does not in and of itself give rise to subsidies within the meaning of the SCM Agreement, government intervention in existing markets may amount to subsidies when they take the form of a financial contribution, or income or price support, and confer a benefit to specific enterprises or industries.' (emphasis in the original)

So, in the eyes of the $\mathrm{AB}$, the examination whether a subsidy has been bestowed is different when the financial contribution is made to an established market, as opposed to cases when a 'new' market is created, and it seems fair to conclude that a demonstration that a subsidy has been bestowed will be 
much harder in the latter case. ${ }^{16}$ As noted above, the Canadian Province of Ontario was 'establishing' a new market through regulation, as opposed to intervening in an existing market, and this meant that the appropriate benchmark for determining a benefit was to be found in a competitive market for renewable energy that has characteristics sufficiently similar to those faced by Ontario. This immediately implies that if such a market can be found, the benchmark price will be higher than that found in the market for conventional power (given the fact, noted above, that renewable energy producers are uncompetitive vis-à-vis conventional energy producers). It also implies that the search for such a market will be difficult - certainly more complex than finding a benchmark price in the existing Ontario wholesale market, for example. This may again favour the case of support to a new market over the case of support to players in existing markets. In the present case this difficulty was the proximate reason for the AB's inability to complete the analysis and determine whether a benefit had been conferred; the $\mathrm{AB}$ cited the, "complexity of the issues and ... the absence of full exploration of the issues before the Panel." ( $\$ 5.244)$

Specificity: recall that for a scheme to be considered a 'subsidy' in the SCM Agreement sense of the term, three requirements must be cumulatively met, namely, a financial contribution by a government, which confers a benefit to a specific recipient. As detailed above, in this case, the AB could not find that a benefit had been bestowed. Hence, it did not need to examine whether the scheme satisfied the specificity-requirement (Art. 2 SCM Agreement) since, even if this were the case, it would still not qualify as subsidy: 'two out of three ain't good enough'.

Conclusion: in Canada-Renewable Energy, the Panel and the $\mathrm{AB}$ (§6.1) concurred that the Canadian measure was a trade-related investment measure that conditioned some advantage on a local content-requirement, and thus was in violation of Art. III.4 GATT. The AB, upholding the outcome but not the approach of the Panel, further held that it was unable to determine that the Canadian scheme was a prohibited subsidy (\$5.246).

\section{A Critique}

\section{III.A. Local Content, Global Mess}

The complaint regarding local content was formulated as follows by the Panel (§7.108): 'The complainants argue that the measures at issue are TRIMs because they (i) encourage investment in the local production of renewable energy generation equipment and components in Ontario; and (ii) affect trade in wind and solar energy generation equipment by favouring Ontario products over imported products.'

Premium rates for electricity should be paid to 'qualifying generators' assuming local content (between 25 and $60 \%$ depending on whether it was solar or wind energy being produced) had been satisfied ( $§ 7.150 \mathrm{ff}$. of the Panel report).

Following the advent of the SCM Agreement, local content requirements are sanctioned by both the GATT as well as the SCM Agreement. There is a twist though: under the SCM Agreement, disputes concerning local content requirements will be adjudicated within short deadlines, and, in case the complainant has been successful, the challenged scheme must be withdrawn 'without delay' (Art.

16 The AB held in $\$ 5.190$ that the relevant benchmark price would be established by finding some market with the same characteristics in which Ontario found itself (given the supply mix of energy products, for example, e.g. the mix between renewable and non-renewable energy). In the (unlikely) event that we could find a perfect market of that sort, there is still the possibility that Ontario's FIT program would still qualify as subsidy, if it involved compensation well above the rates found in that comparator market. Thus the $\mathrm{AB}$ was careful on to say that in and of itself, the mandated supply mix (which creates the new market) did not create a subsidy. But it did not totally exclude the possibility for a government to create a new market and be subsidizing. 
4 SCM Agreement). This is not the case with respect to local content requirements falling under the aegis of the GATT.

The Panel and the $\mathrm{AB}$ found that the challenged scheme involved local content requirements, but could not determine whether they were linked to a subsidy. It is, of course, possible for local content requirements to stand quite apart from any subsidy; this is the case, for example, when local content requirements are of exclusively regulatory nature, e.g. 'in Home, car makers can only use domestic steel for the production of cars'. Can it also be the case when governments provide financial contributions? In other words: should we understand that the TRIMs- and the SCM Agreement are complements, or partial substitutes in this respect?

The Panel used the Illustrative List established in the Annex to the TRIMs Agreement as source of inspiration for its findings. The first two items that are relevant for the present case are reproduced here:

'1. TRIMs that are inconsistent with the obligation of national treatment provided for in paragraph 4 of Article III of GATT 1994 include those which are mandatory or enforceable under domestic law or under administrative rulings, or compliance with which is necessary to obtain an advantage, and which require:

(a) the purchase or use by an enterprise of products of domestic origin or from any domestic source, whether specified in terms of particular products, in terms of volume or value of products, or in terms of a proportion of volume or value of its local production; or

(b) that an enterprise's purchases or use of imported products be limited to an amount related to the volume or value of local products that it exports.'

These are 'regulatory' requirements. There is no financial contribution by the government involved here. This was not the case though, with the subsidies provided by the Canadian Province of Ontario, where a fixed price would be paid to qualifying generators: the requirement to use local content full stop, and payment of money if local content has been used are two different measures; in the former case, no one can use 'foreign' content, whereas in the latter producers who might find it profitable to do so, will go ahead and do so even though they might be foregoing a financial contribution by the government.

It is true that the chapeau to the two examples mentions that complying with the requirements is necessary to obtain an 'advantage' without any further qualification. It could be argued that 'advantage' could be both fiscal, or non-fiscal. In principle, thus, it could be that the term 'advantage' in the context of local content requirements could be some financial contribution. Or could it? We believe that this could never have been the intention of the drafters: financial contributions would come under Art. III.8 GATT (in the GATT-world) and the SCM Agreement (in the WTO-era).

The Indicative List included in the TRIMs Agreement provides support for our claim. In principle, many other TRIMs could come under the aegis of the Agreement. Indicative lists serve two purposes: on the one hand, to help the judge avoid type II errors (since, when encountering facts similar to those appearing in the list, the judge will know that the rule of law applies); on the other, it informs the judge (as well as the WTO Members) about the 'class' of measures that the legislator intended to subsume under the legal discipline had it opted for a 'complete' contract. ${ }^{17}$ By restricting the Illustrative List to examples of 'regulatory' nature, the legislator evidenced its will to subsume only local content requirements of 'regulatory' nature. Local content requirements that involve financial contribution by the government should come under the aegis of the SCM Agreement. ${ }^{18}$

17 Horn et al. (2010) explain why contracts like the WTO are almost obligationally incomplete, be it for reasons of diminishing returns or political realism.

18 This is probably why local content requirements are prohibited subsidies, e.g. there is favourable burden of persuasion that falls on the shoulders of complainants, since there is no need to show specificity, as per Art. 2.3 SCM Agreement which we discuss below. 
In fact, the Panel and the $\mathrm{AB}$ divided the challenged measure in two: a requirement to use domestic generators, and a payment of money as if the two were unrelated. They found against the former, and decided that the latter did not qualify as subsidy for the reasons advanced above. So what if Canada now turns, drops the local content requirement, and continues to provide financial contributions to producers of electricity? Would this measure pass the test of consistency with the WTO? The likelier response is no, and we will return to it in what follows below.

\section{III.B. Supply Substitutability: Handle with Care}

As noted above, the $\mathrm{AB}$ allows for supply side factors to help define the relevant market to be used in the construction of a benchmark. It tries to paint this as in line with previous practice, but the argument is unconvincing. As noted above, it cites a paragraph from the $\mathrm{AB}$ report in EC and Certain Member States - Large Civil Aircraft (para 1121) that is taken out of context. That report cites only one example of a supply side factor that might be necessary to consider: whether a supplier might be able to easily switch its production from one product to another, presumably referring to switching from a subsidized product to a substitute product. This may be relevant to determining serious prejudice, which was in fact the context for the EC and Certain Member States - Large Civil Aircraft discussion. That is, for the purposes of determining serious prejudice it is relevant that Boeing might, absent the subsidies, be able to enter markets held by Airbus. But the fact is that Boeing is not currently in those markets. So this tells us nothing about whether the goods that Boeing is currently producing are part of the same market as the subsidized Airbus aircrafts, whether they are competitive substitutes. In other words, it tells us nothing about whether a benefit has been conferred relative to a benchmark case. The point is that while supply-side factors in this case may be relevant to determining injury, they are irrelevant to determining the definition of the relevant market for the purposes of establishing a benchmark.

The wider implications of the AB's reasoning are significant. If country A sells widgets, and country B's producers come up with a new substitute for widgets that is uncompetitive because of cost structures and other supply-side factors, this ruling seems to give legal flexibility for country B to subsidize its uncompetitive producers. No benefit will be assessed because country B's producers are not in the same market as country A's producers, even though the two goods are substitutes. The cost structure of production, and other uncompetitive supply-side characteristics of the new good, which are the underlying drivers of the need for subsidy, mean that country B's producers are in a different market for the purposes of establishing a benchmark market price.

This seems to grant surprisingly generous leeway to states engaging in industrial policy, in a manner that seems inconsistent with the intent of the drafters of WTO law. Art. XVIII(c) GATT is an exception for infant industry, but it is limited for use by developing countries only. The AB, through its ruling, seems to have opened the door wide to infant industry protection. If this were the intention of the drafters, they would not have restricted it to Art. XVIII(c) GATT; they would have made it possible for the whole Membership to profit from similar possibilities.

Granted, the AB later in its deliberations cautions that there's a difference between support to create a new market and supporting players in an existing market, with prejudice to the latter (\$5.188), indicating that they hope the door will not be completely open. We examine this aspect of the ruling in the next section.

\section{III.C. New and Old Markets: does it Matter?}

Having defined the relevant market for determination of benefit as the market in which electricity from renewable sources is traded, the $A B$ then turns to determining the benchmark price that should be used. In theory (though not in practice), this should be fairly straightforward: since the existing market for renewables in Ontario cannot be used, it should be a matter of finding some Canadian comparator 
market in which the prevailing market conditions were similar to those in Ontario's market for renewable energy - some other jurisdiction that was similarly engaged in actively changing the supply mix to increase the penetration of wind and solar power. If this cannot be found in Canada then, as per US Softwood Lumber $I V,{ }^{19}$ it can be sought outside the country, or a constructed benchmark can be created that is calibrated to account for the prevailing market conditions in Ontario.

But rather than focus on the task at hand, the $\mathrm{AB}$ goes back to, in effect, again justify its decision to use the market for renewables as the relevant market. It argues at some length that the "prevailing market conditions" for the purpose of determining a benchmark include the mandate for increased renewables in the supply mix $(\$ \S 5.183-187)$. But the hazard here is obvious. If a government purchases goods or services at a premium rate in order to achieve some objective - for example economic development - shall we take that objective into account when determining the benchmark price, by finding the prevailing purchase prices in another jurisdiction that has similar objectives for firms in that sector? Lest a precedent be set that allows the intent of any government regulation to affect the benchmark price, the $\mathrm{AB}$ creates what is, in effect, a new distinction, between measures that create a new market, and measures that support active players in existing markets.

\begin{abstract}
'Nevertheless, a distinction should be drawn between, on the one hand, government interventions that create markets that would otherwise not exist and, on the other hand, other types of government interventions in support of certain players in markets that already exist, or to correct market distortions therein. Where a government creates a market, it cannot be said that the government intervention distorts the market, as there would not be a market if the government had not created it. While the creation of markets by a government does not in and of itself give rise to subsidies within the meaning of the SCM Agreement, government interventions in existing markets may amount to subsidies when they take the form of a financial contribution, or income or price support, and confer a benefit to specific enterprises or industries.’ (§5.188)
\end{abstract}

This distinction is closely related to the supply-side analysis discussed above. At the basis of the analysis is the underlying government objective - a certain energy supply mix (we will come back later to consider the significance of this treatment of the government's objectives). Given that objective, and the supply-side factors at play-including cost structures and problems of intermittency - the government was compelled to enact measures that in effect created a new market.

'... even if demand-side factors weigh in favour of defining the relevant market as a single market for electricity generated from all sources of energy, supply-side factors suggest that important differences in cost structures and operating costs and characteristics among generating technologies prevent the very existence of wind power and solar PV generation, absent government definition of the energy supply-mix of electricity generation technologies. This, in turn, [should] have led the Panel to conclude that the benefit comparison under Article 1.1(b) should not be conducted within the competitive wholesale electricity market as a whole, but within competitive markets for wind- and solar PV-generated electricity, which are created by the government definition of the energy supply-mix.' (para 5.178, emphasis added)

There are some problems with this approach. For one thing, the distinction between government intervention that creates new markets, and intervention in an established market has no statutory underpinning. Arts. 1 and 2 SCM Agreement do not contain any language to this effect. As well, and partly as a result of the novelty of the approach, there is no clear guidance on how we might distinguish between new markets and existing ones. It can be difficult to properly delineate a market $a b$ initio: the multimedia market is a proper illustration, where industrial equipment that belonged to different markets has merged into one market. If government support was critical to the underlying technological evolution, could the newness of the market shelter that support from subsidies disciplines, in the way the $\mathrm{AB}$ argues it should for Ontario's renewables support? In the end the

19 WTO Appellate Body Report, United States - Final Countervailing Duty Determination with Respect to Certain Softwood Lumber from Canada (US__Softwood Lumber IV), WT/DS257/AB/R, circulated 19 January 2004. 
new/existing markets distinction may slightly narrow the scope for industrial policy to avoid subsidies disciplines, but the extent and nature of that narrowing are entirely unclear.

\section{III.D. A Victory for Green Measures?}

While the AB's ruling might seem welcome news from an environmental perspective - after all, the "green" part of this measure was not found to be a subsidy - policy makers should not rely on the expectation that the legal acrobatics performed in this case will be repeated. FITs have not been offered a safe haven.

The AB will inevitably have to narrow down its judgment in the future, and no one at this stage can predict by how much. Recall, we held that the distinction between 'establishing' new markets and providing subsidies in 'existing' markets was tenuous for two reasons: first, it is difficult to decide what a new market is; how many wind producers would need to be established in a market for it to be considered an existing market? Is the determinant of newness the degree of market penetration (and if so, at the national or international levels, and to what degree?), or is it the costs of production - the socalled supply-side factors that the $\mathrm{AB}$ held were responsible for their determination that the relevant comparator market was the market for renewables? If the latter, how low do the costs need to fall before we can consider the market to be existing, rather than new?

Second, even if the new/existing market distinction is maintained, and the relevant market is held to be the market for renewables, recall that the $\mathrm{AB}$ in this case has described the sort of information it might need to establish whether a benefit has in fact been conferred. Future complainants can be expected to take guidance from this decision by providing suggested benchmark markets that approximate the conditions found in the implementing jurisdiction. Future panels will have a much harder time blaming a lack of data for the inability to determine a benefit. And when the comparator market is established, of course it will be possible for a FIT to confer a benefit if the remuneration in the implementing jurisdiction is higher than that in the comparator jurisdiction. Relatively generous FIT schemes would likely be found to be subsidies.

Finally, it simply cannot be that in the name of this artificial distinction the door to industrial policy unlimited has been opened. The AB, even assuming it insists on this distinction in the future as well, will need to impose some limits so as to avoid abuses in the name of establishing new markets.

Even the 'cleanest' of green measures would find no safe harbour in facing the SCM Agreement as currently formulated. Imagine a payment to consumers - rather than producers - to compensate them for consumption of higher priced renewable electricity. The SCM Agreement in Art. 1 does not request that the recipient be a producer; Art. 2 SCM Agreement however, dealing with 'specificity' requests that payments be made to an enterprise or group of enterprises, making it thus prima facie impossible for WTO Members to successfully challenge subsidies paid to final consumers of goods. Or is it the case? The 'pass through' jurisprudence has established that plaintiffs can successfully challenge schemes paid to entities other than the direct beneficiary. Assuming for example, that a subsidy to consumers switches demand from non-renewable to renewable energy without affecting the overall volume of consumption, and without privileging a particular producer (say national over foreign), then it will be hard to see how a challenge against similar schemes can ever succeed before the WTO. Conversely, as a result of the scheme it could be that consumers privilege consumption of domestic renewable energy - for example because no foreign producers are supplying power to this market - and in this case, an indirect benefit has been conferred to a particular enterprise or group of enterprises. Only an analysis of the facts can help establish what has actually happened, and distinguish wheat from chaff. The good news is that, contrary to the standard of review employed in Art. III GATT cases, the SCM Agreement requests an effects-test. The bad news is that on occasion judges might find some effects favouring domestic producers (as a result for example of legal import tariffs on energy) and sanction even the 'purest' of green measures. 
In short, those aspiring to adopt similar 'green' and 'blue', or simply 'green' measures should not be overjoyed because of the findings of the $\mathrm{AB}$ in this particular case.

\section{The AB's Dilemma}

The $\mathrm{AB}$ in this case ventured far from familiar ground in some important respects. It invented a new and significant distinction between new and established markets, it resorted to supply-side factors to determine the relevant market, in the process collapsing injury-analysis with market definition. All of this seems to be driven by a reluctance to find that a FIT is in fact a subsidy.

\section{IV.A. It's So Hard to Find a Good FIT}

What is it about the FIT that might have inspired such legal acrobatics on the part of the AB? It is suggested above that the FITs used by Ontario (but not necessarily the conditions attached in the form of LCRs) are designed to foster a global public good: mitigation of climate change. Three things are worth noting about this objective. First, this is a significant good. Climate change has been called the "greatest market failure the world has ever seen," capable, if unaddressed, of shaving off $5 \%$ (and as much as 20\%) of the world's GDP "each year, now and forever." ${ }^{20}$ Almost all of the world's nations have explicit international legal obligations to address the problem. ${ }^{21}$

The second point is that addressing climate change creates global public goods. There is an important distinction between trade-related measures designed to achieve such benefits and those designed to achieve benefits that vest purely at the domestic level. In the latter case, the economic pain of disrupted trade and investment, felt primarily by other countries, is balanced off against benefits felt primarily in the implementing country. In the former case, the costs are the same but the benefits are felt by all - including those suffering the costs of trade and investment disruption. The distinction is material in determining the fundamental propriety of any measure, a task we cannot avoid if we contemplate reform of existing laws.

The third point is that there is nothing protectionist inherent in this measure. A FIT in and of itself, minus the LCR conditions, can and does benefit investors and traded goods from any provenance without discrimination.

Do the measures in question actually address climate change? Certainly we can say that the FIT does, aimed as it is at rapid and extensive deployment of renewable energy generation capacity. Energy related carbon emissions make up a full $70 \%$ of anthropogenic greenhouse gas emissions. ${ }^{22}$ Further, a number of studies have shown that FITS do indeed foster a rapid deployment of capacity for renewably generated electricity. ${ }^{23}$

It would be more difficult to evaluate whether the LCR attached to the FIT in this case also addresses climate change. Its proximate objectives and impacts are entirely rooted in national benefits such as job creation and fostering national firms that can compete at the global level in the renewable energy space. And its immediate cost impacts work against climate change mitigation, since they inevitably increase the cost of installed capacity by forcing investors to source from more costly local

20 Stern (2006). The most recent studies by Stern (2013) and Pindyck (2013) point to the fact that if at all, the size of the problem has been under-estimated.

21 Those obligations are found in the UNFCCC (United Nations Framework Convention on Climate Change (UNFCCC), done at New York, 9 May 1992, 31 ILM 849), Art. 4, and the Kyoto Protocol (Kyoto Protocol to the UNFCCC, (Kyoto Protocol), adopted 11 December 1997, 47 ILM 22), Art. 3. Both developed and developing countries have obligations, albeit of different character, and they exist in both the Convention and the Protocol.

22 IEA (2012).

23 Lipp (2007); Butler and Neuhoff (2008); Fouquet and Johansson (2008); Deutsche Bank (2010). 
suppliers. The only conceivable way in which such a measure could be considered to work toward mitigation of climate change would be to pass a modified version of the "Bastable test". As interpreted by Kent (1960), the Bastable test says that an industrial policy measure is worthwhile if the total costs of support are outweighed by the present discounted value of the benefits derived. A Bastable test that asked about industrial policy's global environmental impacts, rather than its national economic impacts, would count as costs the lost environmental benefits from slower deployment of those technologies. Against this, it would balance off the future environmental benefits of the policy. These might include, if the industrial policy is successful, the environmental impacts resulting from the creation of new innovators and competitors in the environmental technology space. Like the original Bastable test, this modified test is more heuristic than practical; it would be challenging to apply, but it highlights the important considerations at play. And it points to an important truth: if green industrial policy is a failure from the economic perspective, it is necessarily also a failure from the environmental perspective.

We do not believe that the $\mathrm{AB}$ did not consider these issues, even if there is no reflection and explicit mention in the report. In the final analysis, we have one measure (the FIT) that makes an undeniable positive contribution to a global public good - mitigating climate change, and is not protectionist in character. The other measure is harder to assess, and is fundamentally protectionist. The convoluted reasoning of the $\mathrm{AB}$ and the Panel are, in our view, motivated by a desire to find the LCR in breach of WTO obligations, but to avoid finding the FIT itself to be a subsidy. The former result was guaranteed in any case by the finding that the LCR was a prohibited performance requirement under TRIMs. As to the latter, the acrobatics involved in both the Panel and AB reports are testimony to the challenge this entailed under existing law.

What we are suggesting is that the underlying rationale for the FIT was an important consideration in how the measure was treated in the Panel and $\mathrm{AB}$ decisions. The $\mathrm{AB}$, however, protests that such is not the case:

'We understand [the] statements by the Panel to suggest that a benchmark for wind- and solar PVgenerated electricity in Ontario should take into account the government's definition of the energy supply-mix as including wind power and solar PV generation. However, we do not consider that these statements should be interpreted as suggesting that the policy objectives underlying electricity production and supply entirely prevent a market-based approach to the determination of benefit. To do so would mean to read an exception into Article 1.1(b) based on the rationale of the subsidy that has no textual basis in the Agreement.' (\$5.182, emphasis added).

And:

'... while introducing legitimate policy considerations into the determination of benefit cannot be reconciled with Article 1.1(b) of the SCM Agreement, we do not think that a market-based approach to benefit benchmarks excludes taking into account situations where governments intervene to create markets that would otherwise not exist.' ( $\$ 5.185$, emphasis added)

Rather, the $\mathrm{AB}$ argues that its treatment of Ontario's FIT regime is grounded in the newness of the market, and the supply factors that characterize the renewable energy markets - arguments that we have shown above to be fundamentally incomplete. At the same time, the AB in several places takes pains to explain - even defend - the underlying environmental rationale for the government intervention in the electricity market:

'Governments intervene by reducing reliance on fossil energy resources and promoting the generation of electricity from renewable energy resources to ensure the sustainability of electricity markets in the long term. Fossil energy resources are exhaustible, and thus fossil energy needs to be replaced progressively if electricity supply is to be guaranteed in the long term. Government intervention in favour of the substitution of fossil energy with renewable energy today is meant to 
ensure the proper functioning or the existence of an electricity market with a constant and reliable supply of electricity in the long term.' $(\$ 5.186)^{24}$

And:

'We further note that a comparison between renewable energy electricity generators and conventional energy electricity generators requires consideration of the full costs associated with the generation of electricity. In this respect, if, on the one hand, higher prices for renewable electricity have certain positive externalities, such as guaranteeing long-term supply and addressing environmental concerns, on the other hand, lower prices for non-renewable electricity generation have certain negative externalities, such as the adverse impact on human health and the environment of fossil fuel energy emissions and nuclear waste disposal. Considerations related to these externalities will often underlie a government definition of the energy supply-mix and thus be the reason why governments intervene to create markets for renewable electricity generation.' $(\$ 5.189)$

While such statements may be read as arguing the legitimacy and importance of the policy objectives that gave rise to the measures in question, the $\mathrm{AB}$ is careful not to cross the line to arguing that these worthy rationales should be the basis for special treatment under WTO law. But these statements fit well into a pattern of reasoning that seems to seek to protect FITs from a finding of subsidy - a worthy objective for all the reasons summarized above, but one that would be frustrated by the law as it exists.

\section{IV.B. The Turquoise Mess}

The local content requirement attached to the FIT in this case presented relatively few legal difficulties compared to those presented by the FIT itself. As noted above, the Panel found that the local content requirement constituted an investment measure that was inconsistent with GATT Art. III(4), as per TRIMS Agreement Art. 2(1). ${ }^{25}$ This finding was not appealed. Had the FIT been found to be a subsidy, the conditioning of that subsidy on the local content requirement would have certainly meant that it was a prohibited subsidy, as per SCM Agreement Art. 3.1(b).

Unlike the FIT, which has an environmental rationale, the LCR attached to it has an industrial policy rationale. That is, the aim of the LCR is to create jobs, and to help foster infant industries in the covered sector(s). This inherently economic rationale is also at the heart of the trade regime's discomfort with it as a tool. It is designed to divert investment and trade so as to benefit domestic firms at the expense of their foreign competitors.

Does attaching the LCR to an environmentally motivated measure such as the FIT change the picture at all? Does the blue measure (the LCR) actually help achieve the objectives of the green measure? If it did, and if we took the rationale of the measure into account, the LCR attached to an environmental subsidy might merit special treatment.

One way in which the LCR might help achieve environmental gains is as argued in the previous section: it might successfully propel an infant industry into a mature innovating competitor in a space that urgently needs more innovation and competition. As noted above, though, any such environmental gains would have to be balanced against the short term environmental costs of forcing environmental goods to come at higher prices (the environmental Bastable test).

Another way an LCR might help achieve environmental goals is by making environmental measure politically feasible. That is, for example, it may have been politically impossible to sell Ontario

\footnotetext{
24 This again is somewhat "acrobatic" in the sense we use above. Ontario's policies to foster renewable capacity are not motivated by any looming shortage of exhaustible fuel, the predominant traditional modes of generation being coal and nuclear. To describe FITs as analogous to other policies aimed at long-term sustainability of supply is to praise them for what they are not.

25 Panel Reports, Canada-Renewable Energy, above n 4, para 7.167.
} 
consumers the idea of higher costs of electricity just for environmental reasons, even if price hikes were justified on social welfare grounds. It is much easier for a politician to convince the electorate to go along with environmental measures if they can be said to also bring economic benefit. This is the political attractiveness of the so-called green economy paradigm. ${ }^{26}$

It is difficult to see the political feasibility rationale justifying an exception to trade rules. This is not so much a slippery slope as a sudden cliff. Protectionist measures are inherently politically popular, so it would be unwise to open a door for measures on the grounds that they were a necessary evil to enable the passage of some good policy.

Somewhat more plausible is an exception based on the grounds that the measure passed the environmental Bastable test. But even this would be difficult. Obviously assessing the environmental benefits and costs would be challenging, but there are more fundamental problems. The GATT Article XX exceptions, while arguably not applicable to subsidies, reflect the prevailing notion that we need to separate legitimate environmental measures from those that are disguised protectionism, as if all environmental measures can be cleanly divided into one or the other camp. The job of Article XX's chapeau is among other things to perform this division. Green industrial policy measures, however, necessarily occupy both camps at once. When green and blue measures mix to become turquoise, things get messy. ${ }^{27}$

\section{What Could the AB Have Done?}

Before we go any further, we should re-iterate that, by virtue of Art. 3.2 DSU (Dispute Settlement Understanding), the WTO Agreement administering dispute adjudication, Panels and the AB cannot undo the balance of rights and obligations that the WTO Members have struck: they cannot add to the obligations agreed, as they cannot diminish the acknowledged rights.

The SCM Agreement distinguishes between actionable and prohibited subsidies. A third category, the so-called non-actionable subsidies, ceased to exist in 2000, and we will return to this issue below. As discussed above, the $\mathrm{AB}$ was unable to find that a benefit had been bestowed through the FIT Programme and the MicroFit Contracts in Canada-Renewable Energy. We explained why this approach was tenuous to say the least, and why we cannot expect to see it repeated in future decisions. Was there a better way that the AB could have used to avoid finding the FIT in breach of WTO obligations?

\section{V.A. Is an Art. XX GATT Defence Possible?}

The FIT has characteristics that would have made it liable to be saved by Article XX GATT, were the measure in question a restriction on trade in goods, as opposed to a support measure cum subsidy. Case law has not addressed the issue whether Art. XX GATT can serve as exception to violations of the SCM Agreement. The law itself is silent on this issue.

Rubini (2012) has argued that, in case there is no agreement to reinstate non-actionable subsidies in the SCM Agreement, Art. XX GATT could be an acceptable second-best since it would allow for subsidies ostensibly justified on environmental grounds to become de facto non-actionable. Howse (2010) has expressed similar views arguing that understanding Art. XX GATT as exception to violations of SCM Agreement is probably necessary since the SCM Agreement itself does not distinguish between subsidies that distort, and subsidies that address distortions. Lester (2011) advances arguments in favour of constructing the SCM Agreement as a means of fighting against

$\begin{array}{ll}26 & \text { UNEP (2011). } \\ 27 & \text { Rubini (2012). }\end{array}$ 
'protectionist' subsidies only, that is, subsidies void of a public policy rationale other than to increase the income of producers. ${ }^{28}$

At the heart of similar claims lies the frustration of trade experts with the absence of recognition in the SCM Agreement context of the reason for subsidization. Subsidies might be a very appropriate instrument to deal with market distortions and, as the saying goes, 'markets work well when it comes to ice cream, but not necessarily so when it comes to clean air'. Is however, this argument legally sustainable?

There is, of course, partial overlap between the list of Art. XX GATT, and the list in Art. 8 SCM Agreement: 'green' subsidies could come under Art. XX(b) and XX(g) GATT anyway. The negotiating record strongly indicates that the idea was to examine 'green' subsidies in a self-contained manner in the SCM Agreement context: documents by the Secretariat, ${ }^{29}$ the Chairman of the Negotiating Group on Trade Environment, ${ }^{30}$ as well as by various WTO Members belonging to different alliances, such as New Zealand, ${ }^{31}$ India, ${ }^{32}$ and Austria on behalf of EFTA (European Free Trade Association), ${ }^{33}$ strongly support the conclusion that Art. 8 SCM Agreement was not thought of as an add-on to Art. XX GATT, but rather as the only provision dealing with subsidies not bound by the disciplines embedded in the SCM Agreement.

Moreover, an affirmative response to the question (is Art. XX GATT an exception to the SCM Agreement?) would almost axiomatically fail the test of consistency with the chapeau of Art. XX GATT which calls for absence of discrimination across countries where similar situations prevail: it cannot have been the intent of WTO Members to allow discriminatory payment of subsidies only to national firms through Art. III.8(b) GATT, only to reverse that allowance through the back door (Art. XX GATT).

\section{V.B. A Specificity Defence}

Art. 2.3 SCM Agreement reads: 'Any subsidy falling under the provisions of Article 3 shall be deemed to be specific.'

How does this play out in Canada-Renewable Energy? There is financial contribution to producers (in principle, an un-identified number of private parties as well) of renewable energy. If there was no local content-requirement, then maybe the scheme would have been hailed non-specific. We say maybe, because the limits of de facto specificity are quite fuzzy in case law: subsidies which have not been limited to few enterprises, or which have been provided in accordance with objective criteria, can still be specific. To decide if this has indeed been the case, an investigating authority must review whether the scheme is (Art. 2.1(c) SCM Agreement):

(a) Used by a limited number of enterprises;

(b) Predominant used by certain enterprises;

(c) Disproportionately large amounts to certain enterprises;

(d) Manner in which discretion has been exercised to grant a subsidy.

\footnotetext{
28 Sykes (2005) has not argued along these lines, but provided the most comprehensive attack on the current sub-optimal (from an economic theory perspective) design of the SCM Agreement.

29 GATT Doc. L/6896 of 18 September 1991.

30 GATT Doc. Spec (91)21 of 29 April 1991.

31 GATT Doc. Spec (91)36 of 8 July 1991.

32 GATT Doc. Spec (91)40 of 9 July 1991.

33 GATT Doc. Spec (91)27 of 12 June 1991.
} 
There is no obligation to examine all four factors, as the Panel on US-Softwood Lumber IV made clear: ${ }^{34}$ in this case, Canada had argued that the Canadian government had never intentionally limited access to the stumpage programmes; in its view, the predominant use of the stumpage programmes by lumber producers could be explained by the fact that the alleged financial contribution consisted of the provision of trees, which, thanks to inherent characteristics, are of interest mainly to a limited number of $\log$ and lumber producers. The Panel was of the view that there was no need to show intent in order to satisfy the de facto specificity requirement, although deliberate action by the government might be revealing; what matters is that one (at least) of the four criteria mentioned in Art. 2.1(c) SCM Agreement had been met: in this case, stumpage programmes could only benefit lumber producers (\$7.116).

In the case we discuss though, there was a local content requirement, so the Panel (and the $\mathrm{AB}$ ) took the view that they were facing a discreet choice: either the scheme was a prohibited subsidy, or no subsidy at all. In other words, they treated the presumption established in Art. 2.3 SCM Agreement as irrebuttable.

So far there has been no case where, in presence of a finding that a subsidy is prohibited, WTO adjudicating bodies also examined to what extent it was specific. It seems thus, that the Panel and the $\mathrm{AB}$ would be breaking new grounds had they decided to ask whether the subsidy were specific.

Moreover, had they done so, one might legitimately ask what the difference between prohibited and actionable subsidies after all is? In both cases, a financial contribution must bestow a benefit to specific recipients; in case of non-implementation, following US-Upland Cotton (Art. 22.6-US), countermeasures against recalcitrant WTO Members will be calculated using the same formula. It follows that the only substantive difference between the two has to do with the presumptive specificity as far as prohibited subsidies are concerned. If this becomes a rebuttable presumption, then differences have vanished. This cannot be.

These are thus, strong arguments for constructing Art. 2.3 SCM Agreement as a provision that establishes irrebutable presumption.

\section{V.C. Public Goods}

There is nothing like a public goods-defence in the SCM Agreement either. Prima facie, one would be tempted to suggest that any of the 'specificity'-provision (Art. 2 SCM Agreement), the benefits test, or Art. 8 SCM Agreement were supposed to play this role. Since the latter provision has been rescinded, the question arises to what extent the former suffices as is to play this role.

A negative response is warranted: governments might have to provide monetary incentives to a few enterprises (specific contributions) in order for the society at large to enjoy say clean air; they do not have to provide monetary incentives to the whole society (non-specific) to achieve this goal. Actually, this was the rationale behind Art. 8 SCM Agreement in the first place: it was meant to allow specific subsidies stay in place without the risk of facing countermeasures.

Is a benefit though, being provided to operators when they receive money in order to produce a public good? Or, better, was 'benefit' inserted in the SCM Agreement in order to capture situations where a public good is being conferred? ${ }^{35}$ It can be argued that payment to firms that create public goods is simply payment of the full benefits conferred by the firm's actions - an internalization of external environmental costs.

\footnotetext{
34 Appellate Body Report, US - Softwood Lumber IV, above n 15, para 7.123.

35 Mavroidis (2012) discusses the attitude of WTO towards public goods.
} 
It is widely acknowledged that governments have a duty to address environmental problems within their territories, and a number of international legal agreements commit states to also addressing global environmental issues such as climate change. Customary international law, as summarized in the Rio Declaration on Environment and Development, affirms that "States have ... the responsibility to ensure that activities within their jurisdiction or control do not cause damage to the environment of other States or of areas beyond the limits of national jurisdiction." ${ }^{36}$ Under the UNFCCC, Parties agree that they shall, inter alia "formulate [and] implement ... programmes containing measures to mitigate climate change." ${ }^{37}$ One of the most important routes for such action is via tax and regulatory policy that internalizes environmental costs, but the scale of the climate change problem dictates that this will not be enough; in some sectors we will also need government support for early stage commercialization of mitigation technologies - policy designed to have governments pay the necessary price for achieving broad social benefits. ${ }^{38}$

If we imagined a scenario in which a government's financial contributions were somehow exactly matched to the unpaid social benefits that would be derived from the investment that they support, then the question would be whether this could be correctly construed as a benefit to the receiving firm. Certainly there is the possibility that such payments would put the firm in an advantaged competitive position relative to its unsupported competitors. But in such a case it would be the unsupported competitors, and not the receiving firm, that faced inaccurate market price signals, raising the question of what is the appropriate market against which to benchmark.

Clearly it would be difficult to determine whether a given subsidy exactly matched the social benefits it created. ${ }^{39}$ It is not suggested here that such a calculation be made in cases such as the one at hand. But it is suggested that the conventional approach is inadequate when dealing with government support that aims to internalize external benefits.

So within the existing law, could the $\mathrm{AB}$ have used this sort of reasoning to find that the FIT was not in fact a subsidy? The absence of a distinction across subsidies using the rationale (or legislative intent) as criterion, leads us to respond in the negative here as well. ${ }^{40}$

\section{V.D. Non-Actionable Subsidies}

\section{V.D.1. Is the Provision on Non-Actionable Subsidies Legally Relevant?}

Three types of subsidies were considered non-actionable: regional aid, environmental subsidies, and subsidies for research and development $(\mathrm{R} \& \mathrm{D})$ purposes, provided they did not exceed agreed quantitative thresholds. They were initially contracted for a five-year provisional period. In the absence of agreement to keep this category in place, non-actionable subsidies ceased to exist as of 1 January 2000 (Art. 31 SCM Agreement). Consequently, a scheme which qualifies as a subsidy under the SCM Agreement is, nowadays, either a prohibited or an actionable subsidy. ${ }^{41}$

36 Rio Declaration on Environment and Development, done at Rio de Janeiro, 14 June 1992, 31 ILM 874, Principle 2.

37 UNFCCC, Article 4(d).

38 Stern (2006).

39 In the present case it could be argued that a portion of the FIT premium should probably be attributed to non-climate goals like job creation, since that premium reflects both the environmental goals embodied in the Fit and the economic goals embodied in the LCR.

40 The Panel accepted an amicus curiae brief that made this argument on benefit, but evidently decided against using it. See International Institute for Sustainable Development et al. (2012).

41 Both Howse (2010) and Rubini (2010) have voiced their concerns over the deletion of non-actionable subsidies from the SCM Agreement: in the current fight against climate change, their usefulness, so goes the argument, should not be underestimated. 
Should deletion be equated to legal irrelevance? Art. 6.1 SCM Agreement has been rescinded by virtue of the same provision (Art. 31 SCM Agreement), and yet Panels continuously use it as legal context. Art. 6.1 SCM Agreement provides the complainant with an important evidentiary advantage, since it is relieved of the burden to demonstrate the prejudicial effects of a subsidy. The Panel on US-Upland Cotton took the view that it could still provide useful guidance in interpreting serious prejudice (footnote 1487 of the report), even if the evidentiary advantage has ceased. The Panel on Korea-Commercial Vessels evidences a similar attitude (\$7.583).

The legal relevance of this provision though is largely due to the fact that, while Art. 6.1 SCM Agreement has been rescinded, the concept of 'serious prejudice' has not. It is very much alive. Conversely, as we briefly discuss in what follows, the concept of non-actionable subsidies has been taken out from the WTO arsenal of rights and obligations.

\section{V.D.2. The Origin of Art. 8 SCM Agreement in the Tokyo Round}

The distinction between 'prohibited', 'actionable', and 'non-actionable' subsidies has been colloquially known as the 'traffic light' approach. The 'traffic light' approach was first proposed by the US during the Tokyo round. The US proposal distinguished between 'prohibited', 'conditional', and 'permitted' subsidies in the following terms:

'New international rules, on subsidies and offsetting measures 'should deal with all three of these problems. The objective of these rules would be to categorize all types of subsidy practices and set forth the conditions by which offsetting measures could be taken against such practices. In particular, rules are needed to:

1) Effectively delineate that category of subsidies that should be prohibited;

2) Place limits and constraints on the use of domestic subsidies' that benefit exports to the detriment of other nations;

3) Delineate which subsidy measures should be permitted;

Permitted. The permitted category would consist of practices that are considered to have minimal impact on international trade. Permitted practices would be limited to those specifically agreed as falling within that category. Such practices and any practices judged to result in a de minimis subsidy, would not be subject to offsetting measures. ${ }^{, 42}$

The US proposal made waves, and was reflected in various official GATT publications:

'In 1975 a proposal was tabled that there should be an international code to deal with export subsidies, third country subsidization, import-replacing measures, and offsetting measures. The code should categorize all types of subsidy practices and set out the conditions on which offsetting measures could be taken against such practices. Subsidies should be divided into the following three categories:

- prohibited (practices designed to increase the competitiveness of national producers, thereby distorting international trade);

- $\quad$ conditional (practices directed toward domestic economic, political or social objectives, but which may distort international trade);

- permitted (practices with little or no impact on international trade against which offsetting measures could not be taken). Although this proposal was not maintained as a basis for the negotiations, elements of it were eventually carried over into the final Agreement. ${ }^{43}$

42 MTN/NTM/W/26, 28 October 1975, at pp. 7 and 8.

43 GATT, The Tokyo Round of Multilateral Negotiations, Report by the Director-General of the GATT, 1979, at p. 57, The GATT: Geneva. 
The GATT Activities of 1975 even reflect a passage where the term 'traffic light' had been privileged, although environmental subsidies were not explicitly mentioned:

\begin{abstract}
'One suggestion would have a new single international code which would classify export subsidies into three major categories: prohibited, intermediate, and permitted practices. The intermediate category in this "tricolour" or "traffic light" scheme, as it has been dubbed, could include incentives such as research and development grants, regional development grants and the like. ${ }^{44}$
\end{abstract}

Eventually, the US dropped the proposal. In an effort to facilitate the conclusion of the round, they shifted the focus of the negotiation towards the issues that would form the bedrock of the Tokyo round agreement. This is how Winham (1986:173) recounts the events:

'In a major initiative, the United States agreed in principle to work from existing GATT rules on subsidy/countervail, which carried the implication of moving toward an international definition of material injury. The United States also dropped the traffic-light approach that rested on the notion of defining prohibited categories of subsidies. Negotiation on this basis quickly isolated the irreducible minimum for both partners. On the American side, this was the need to demonstrate that the Europeans were willing to accept increased international surveillance and discipline on the use of subsidies, while on the European side it was simply a matter of having the Americans accept a material injury clause in their countervail legislation. These two demands eventually formed the basic quid pro quo of the subsidy/countervail negotiation.'

\title{
V.D.3. Resurface in the Uruguay Round
}

It was first the EU that brought back the issue of non-actionable (permitted) subsidies during the negotiations of the Uruguay round. The original EU proposal though did not see room for 'green' subsidies: generally available- (e.g. tax concessions), regional-, structural adjustment-, and indirect subsidies (e.g. subsidies to input products) exhausted the realm of permitted subsidies. ${ }^{45}$ Colombia followed suit and proposed illustrative lists for each category of subsidies (for permitted subsidies as well). ${ }^{46}$ Switzerland followed soon along the same lines. ${ }^{47}$

The various proposals found their way in the so-called 'Cartland drafts' named after Mike Cartland, the Ambassador for Hong Kong, China who was chairing the negotiating group on Subsidies. Eventually, environmental subsidies found their way there and the (original) idea was that non-recurring subsidies would be paid in order to adapt existing facilities to new environmental requirements; the idea was that similar subsidies would be required if, as a result of the new environmental standards, economic operators would have to incur considerable financial burden. ${ }^{48}$

The US was originally hostile to the idea of introducing a category of permitted subsidies: the Carter administration of the Tokyo round had given way to the Reagan administration which was in place when the Uruguay round was launched (and the Bush administration that followed in the same wavelength). In 1992 though, the Clinton administration came to office and this event marked a sudden and complete shift in the US position: in November/December 1993, we observe an oscillation from the Bush Administration's attempt to remove green light categories to the Clinton Administration's attempt to expand them. ${ }^{49}$

\footnotetext{
44 GATT Activities in 1975, April 1976, at p. 19, The GATT: Geneva.

45 MTN.GNG/NG10/W/7 of 11 June 1987, at pp. 4-5.

46 MTN.GNG/NG10/W/13 of 9 September 1987.

47 MTN.GNG/NG10/W/17 of 1 February 1988.

48 McDonough (1993) at pp. 901ff., and especially pp. 908-909.

49 Hoekman and Mavroidis (1996); Horlick and Clarke (1994); Paemen and Bentsch (1995).
} 


\section{V.D.4. The Compromise}

Art. 8 SCM Agreement reflects the final compromise, where three categories of subsidies (environmental subsidies figuring prominently therein) would be 'tolerated' assuming a certain 'cap' (in the form of total financial contribution) would not be violated. Art. 31 SCM Agreement clarified that this provision was of temporary nature:

'The provisions of paragraph 1 of Article 6 and the provisions of Article 8 and Article 9 shall apply for a period of five years, beginning with the date of entry into force of the WTO Agreement. Not later than 180 days before the end of this period, the Committee shall review the operation of those provisions, with a view to determining whether to extend their application, either as presently drafted or in a modified form, for a further period.'

\section{V.D.5. Abandoning Art. 8 SCM Agreement}

Art. 8 SCM Agreement expired at the end of 2000. It is clear that there was no consensus to renew it. It is unclear why this has been the case. The discussions before the SCM Agreement Committee reveal a divide between developed and developing countries: the former were in favour of keeping it in place, the latter saw no use in the list of Art. 8 SCM Agreement. ${ }^{50}$

The minutes of the SCM Agreement Committee reveal a second attempt to save this provision, alas to no avail: Switzerland underscored that it would be bad publicity for the WTO to do away with 'green' subsidies; US gave a half-hearted backing to the Swiss proposal; Brazil speaking for most developing countries argued that the list would be maintained only if its content would be modified so as to suit the interests of developing countries. ${ }^{51}$ No one was prepared to start negotiating the content of Art. 8 SCM Agreement anew, and no discussions on this item are reflected in the subsequent meetings of the SCM Agreement Committee. ${ }^{52}$

A different explanation is equally (if not even more) plausible: Stewart (1993) has taken the view that there was ab initio a trade-off between Art. 6.1 and 8 SCM Agreement, in the sense that extending the life of non-actionable subsidies was always conditional on agreeing on stronger disciplines through presumptions of adverse effects for subsidies; since WTO Members could not agree on the latter, they would not agree on the former either. ${ }^{53}$

\section{Options for Reform: We Cannot Rely on Judicial Acrobatics Forever}

We have argued above that we cannot expect an encore performance of the acrobatics performed in this case. Moreover, we should not hope for such a thing. Acrobatics lack methodology; if role of judge is to complete 'incomplete' contracts as per Horn et al. (2010), then methodology is key in completion since transactions are idiosyncratic and one can drive a wedge through facts; but the manner in which we should think about them is (should be) constant: judges should prepare their own demise by making the resolution of the marginal transaction eminently predictable (assuming of course no distinguishing factors)

\footnotetext{
50 With some WTO Members crossing the floor: Australia was not in favour of extension, Mexico was, see WTO Doc. G/SCM Agreement/M/22 of 17 February 2000.

51 WTO Doc. G/SCM Agreement/M/24 of 26 April 2000. See also Bigdeli (2011) and Casier et al. (2013).

52 See, for example WTO Doc. G/SCM/M/25 of 22 September 2000, and G/SCM/M/26 of 30 March 2001.

53 Stewart (1993) at pp. 228-32.
} 


\section{VI.A. A Return is not Enough}

If adjudication does not look as the most promising avenue to advance similar concerns, then why not simply re-instate Art. 8 SCM Agreement? The discussion before the SCM Agreement Committee shows that there was no unanimity to eliminate Art. 8 SCM Agreement: a number of WTO members wanted to keep it alive for a few more years and then decide. Presumably, some voices in favour of reinstating Art. 8 SCM Agreement can still be found in the WTO Membership. And, of course, negotiators might have found it easier to re-instate Art. 8 SCM Agreement, rather than negotiate from the start a new provision to this effect.

We believe however, that re-instating this provision is not the solution. First, the statutory caps might be an issue. Recall that Art. 8.2 SCM Agreement read:

'assistance to promote adaptation of existing facilities to new environmental requirements imposed by law and/or regulations which result in greater constraints and financial burden on firms, provided that the assistance:

(i) is a one-time non-recurring measure; and

(ii) is limited to 20 per cent of the cost of adaptation; and

(iii) does not cover the cost of replacing and operating the assisted investment, which must be fully borne by firms; and

(iv) is directly linked to and proportionate to a firm's planned reduction of nuisances and pollution, and does not cover any manufacturing cost savings which may be achieved; and

(v) is available to all firms which can adopt the new equipment and/or production processes.'

Second, sometimes there is osmosis in the border between environmental protection and public health: does it make sense to allow one and not the other, when subsidies, assuming good faith, on both occasions would be addressing the under- (or non) supply of a public good? A 'wider' exemption is warranted; more on this later.

For all these reasons, we believe that negotiators should rethink the SCM Agreement, and ideally de-link its negotiation from the stalling Doha round negotiations. We will try to show in what follows that, as a matter of (economic) logic, lumping all subsidies in one basket is simply wrong. Distinctions based on the rationale of subsidization must be drawn. It is high time, negotiators return to the table and agree that the rationale for subsidies matters to distinguish wheat from chaff, and this is what this case underscored: subsidies can distort, as they can address distortions.

\section{VI.B. Economic Theory and why the Rationale for Subsidies Matters}

From an economic perspective, subsidies are a tool like any other, in some cases suited to purpose and in other cases not. There are cases when subsidies are preferable to tariffs; where firms are underinvesting or not entering a market because they face high average costs and increasing returns to scale, a subsidy may be the first best instrument. ${ }^{54}$ As an instrument of protection subsidies, unlike tariffs, do not raise the domestic price of the protected goods above world prices, and therefore have potential to be less distortionary. ${ }^{55}$ In practice economists tend to dislike subsidies because they create opportunities for rent-seeking and capture of policy making processes by vested interests. But in theory, for economists "subsidy" is not a four-letter word.

Trade law also does not proscribe all subsidies, of course. But as Sykes (2005) argues, the nature of the restrictions in trade law does not always correspond to what economic theory would suggest appropriate. There is no reason to believe, for example, that specific subsidies are necessarily less trade-distorting than general subsidies. As well, subsidy law fails to account for total impact of

\footnotetext{
54 Bagwell and Mavroidis (2010).

55 Clearly it matters what distortions are introduced by government taxation to fund the subsidy.
} 
government actions when determining a benchmark, focusing instead on the single measure at issue. And, important to the present analysis,
'... even when an industry is a net beneficiary of government largesse, those benefits may be socially justifiable. Some industries may be a source of positive external economies (most likely in the high technology area) ... Aside from the now expired "green light" subsidy rules, ... WTO law does nothing to address the question whether the ostensible "subsidy" addresses some legitimate problem. ${ }^{, 56}$

There is a vast literature on the economics of subsidies, but the consensus seems to be that they can be appropriate tools to use in addressing certain market failures. ${ }^{57}$ If a firm is significantly underinvesting in R\&D, for example, in the knowledge that some of the benefits of its research will be appropriated by others (this effect has been found to be significant in high tech sectors, as Sykes notes above), it makes sense to subsidize research and development. Note, however, that the rationale matters to the instrument design. If the aim is to overcome underinvestment in R\&D it would make little sense to provide a subsidy tied to output or exports, since such a subsidy would be available to both the innovators and the appropriators, and would likely have no impact on R\&D spending levels. Similarly, if the market failure to be addressed is the presence of potential cost reductions that can only be achieved through learning by doing, and the firm faces imperfect capital markets, then a productionbased subsidy makes sense. It is imperative for the effective use of subsidies that the instrument be tailored to address the specific market failure being addressed. ${ }^{58}$

Those market failures can be of many different types. Under-investment in R\&D and learning by doing were mentioned above. Another important type of market failure is the divergence of market prices and social costs. Consider a producer of electricity from wind, for example, selling power into the grid at the same rates as conventional producers. The price paid to the conventional producers typically does not factor in the environmental damage done by their production, and the price paid to the wind power producer would not factor in the social benefits of avoided environmental damage. As such, from society's perspective the free market solution would see a sub-optimal level of wind power production. Subsidies such as FITs can remedy this by working to equate the social benefits derived from wind power to the private returns going to the producer.

The rationale, however, is critical. It dictates not only which instruments are fit to purpose but, as well, which instruments we might want to legally proscribe. We may well be able to justify subsidies addressing market failure for a wind producer, but that is a very different matter than trying to justify subsidies that do not address any market failure, and that transfer public wealth to private interests in an effort to protect them from foreign competition. We may in fact hold some objectives so important that we can find multilateral tolerance for trade and investment disruption in their service. Of course we have already done so in the context of trade in goods; this is the essence of the General Exceptions embedded in Art. XX GATT. ${ }^{59}$

The measure at issue in Canada - Renewable Energy makes the case powerfully. The FIT, minus the LCR, is aimed at an objective that all nations agree is critically important, and that most have legal obligations to address. It is not protectionist in intent or effect. Its objective is to rectify a significant market failure - the failure to correctly price the environmental costs and benefits of electricity in the Ontario wholesale market. The FIT plus the LCR might conceivably be similarly justified from an

\footnotetext{
56 Sykes (2005). Similarly, Mavroidis (2012:740) argues: “The question whether a domestic policy yields a public good or not is simply immaterial to WTO law ..."

57 Cosbey (2013) summarizes the literature on the various types of market failures that might justify subsidies and other tools of industrial policy.

58 Grossman (1990), Rodrik (2004), Sykes (2005).

59 Rubini (2010; 2012).
} 
industrial policy perspective if it can be shown that it is addressing market failure, but as argued above this would be difficult.

And so, we conclude, that rationale should play a role in determining how subsidies are treated under WTO law, but there is no scope within the existing SCM Agreement for such differential treatment. As such, a redrafting must be contemplated. The question then is how to build such treatment into trade and investment law without at the same time inviting misuse of the exception. It is to this question that the next section turns.

\section{VI.C. A New Expanded Art. 8 SCM Agreement}

We have argued that trade law needs to deal with subsidies in a more nuanced manner, distinguishing between those that have public goods rationales and those that merely transfer income from taxpayers to protect domestic firms. The present case highlights that need. The dangerous legal acrobatics that seem to have been necessary to protect the FIT from being found a subsidy are in themselves a particularly strong argument for reforming the status quo.

This sort of rationale-based treatment is already in force in the context of trade in goods. But we noted our skepticism that Art. XX GATT could be successfully imported to apply to the SCM Agreement, as welcome a development as that might be. We also noted the inapplicability of the exceptions included in Art. 8 SCM Agreement - the rationale-based category of non-actionable subsidies.

In any case, the Art. 8 SCM Agreement type formulation seems too narrow in scope to address the needs highlighted here. It offers shelter to a very limited number of support measures based on type and characteristics. In the context of environmental subsidies, it covers only one-time non-recurring payments for a small percentage of the costs of adaptation to new environmental regulations. If this exception were in force today, it would be of no use in saving the Ontario FIT or any other measure aimed at achieving global public goods through subsidies. ${ }^{60}$ The Art. XX GATT approach, by contrast, is much broader. It sets out those objectives that the Parties hold to be important enough to justify breaches of such important principles as non-discrimination, and then tries to ensure safeguards that will weed out any measures that are not legitimately aimed at such ends. This approach seems to us to be closer to what is needed.

That said, we appreciate the sensitivity of the proposition that some subsidies should enjoy essentially non-actionable status under the SCM Agreement. Subsidies to domestic firms can not only act to nullify and impair liberalization commitments by shutting out foreign competitors, but can also damage foreign competitors' access to third country markets. Any carve-outs would have to be carefully circumscribed. Art. 8 SCM Agreement contains restrictions that were formulated in the spirit of this cautious approach. ${ }^{61}$

In that vein, a hybrid approach that incorporated elements of Art. XX GATT and Art. 8 SCM Agreement might be most appropriate for a rationale-based set of exceptions. We might start with an Art. XX GATT-like set of acceptable objectives, and then add some prescriptive restrictions based on what we know about subsidies. We know, for example, that subsidies that address market failures

60 Moreover, it can be argued that the exception as delineated in Article 8 flies in the face of economic sense; it does not address any market failure, and moreover contravenes the polluter pays principle (Sykes 2005).

61 Note that the EU has a totally different scheme: all subsidies are deemed illegal unless cleared by the common agent, the Commission. To this effect, EU Member states are required to notify the Commission of their schemes. They are encouraged to notify it of even schemes which might 'fall into the cracks' so to speak, for fear of committing a type II error. Cross-notifications are possible, and the Commission itself has substantive investigative powers to this effect. This regime covers state subsidies. EU subsidies are of course legal under EU law (and could be questionable under WTO law only). There are various studies discussing the efficiency of the EU 'centralized' regime. Suffice to state here that there has never been any talk to move to a similar regime in the WTO context as well. 
should be focused on the specific market failure in question. Too many subsidies are blunt, in the sense that their impact goes far beyond what is necessary to address the problem in question. We also know that it is wise to build explicit provisions for the sunset of subsidies, lest they become entrenched and politically impossible to remove even after they no longer serve the need they first set out to address.

As to the acceptable types of subsidies to be covered under such provisions, we see the value of offering shelter to subsidies that pursue global public goods - goods that have benefits beyond the border of the implementing country. These would include subsidies that internalize externalities with respect to climate change (as do FITs, and free allowances under cap and trade schemes), or that advance research and development in clean technologies. This could be covered by outlining the objective broadly (i.e., protection of global environmental resources), in a way that allows for measures devoted to more than just climate change, including biodiversity preservation, reduction of ocean pollution and prevention of desertification, for example.

We also see value in providing exceptions for basic research and development, and for public health subsidies. The potential spillover benefits from this type of activity make it similar to the pursuit of global environmental protection in our minds. While we see these sorts of rationales as important enough to merit exception on their own terms, it is worth noting that limiting exceptions to measures with spillover benefits goes some way to compensating for the potential harm they might inflict on other Parties.

There may also be value in providing exceptions for subsidies determined to be minimally trade distorting. There was strong agreement for including such subsidies in the non-actionable category of subsidies in the negotiations for SCM Agreement's Article 8. ${ }^{62}$ Such exceptions fall outside of our thrust in this paper, being based on factors other than rationale. And it may be that the requirement to show adverse effects (in the case of actionable subsidies) already provides for this kind of protection.

The question arises whether any such exception would need the equivalent of the chapeau to GATT Art. XX - a filter to weed out those measures that are in fact aimed at economic ends rather than those specified in the text. In the context of trade in goods this provision has proved its usefulness. This, however, is where the turquoise mess becomes evident. A straight FIT would easily pass such a filter, but a FIT with local content requirements would not, as LCR is a tool of industrial policy. It was noted above, though, that the LCR in the present case might be argued to have environmental ends, if it passed the environmental Bastable test by creating more environmental benefits than costs. But it would be challenging to give expression of such nuance in legal terms, just as it would to actually estimate the costs and benefits in economic terms.

\section{Concluding Remarks}

In this paper, we have argued in favour of redrafting the SCM Agreement so as to account for the rationale of subsidies, and avoid punishing subsidies aiming for example, at promoting a public good. We did not rush into this conclusion: we checked case law as it has evolved through the landmark Canada-Renewable Energy, and concluded that for good reasons this should be understood as a 'one off' judgment, that cannot be relied upon in order to save from legal challenges measures aiming to correct environmental distortions in the future as well. Worse, it is not clear at all whether measures aiming to subsidize production of renewable energy can pass muster even if they were void of local content requirements.

We understand of course that at this juncture, with the Doha round about to be derailed for good or saved at a very minor scale, the last thing negotiators would want is to add a new negotiating item to

62 Cassier et al. (2013). 
their agenda. And yet, reforming the trade regime so as to be in position to effectively respond to global challenges like climate change would be a strong signal that the world community can still speak with one voice when necessary. It would further reinforce the role of the WTO at a moment when its continued relevance is being strongly undermined as a result of the myriad of preferential trade agreements that see the light of the day, and the trade initiatives that conspicuously find new homes far from Geneva. 


\section{References}

Bagwell, Kyle, and Petros C. Mavroidis. 2010. "Too Much, Too Little,.. .Too Late?” in Kyle W. Bagwell, George A. Bermann, and Petros C. Mavroidis (eds.), Law and Economics of Contingent Protection in International Trade, Cambridge University Press: Cambridge, UK, pp. 168-171.

Bigdeli, Sadeq Z. 2011. "Resurrecting the Dead? The Expired Non-Actionable Subsidies and the Lingering Question of Green Space", Manchester Journal of International Economic Law, 8: 2-37.

Butler, Lucy and Karsten Neuhoff. 2008. "Comparison of feed-in tariff, quota and auction mechanisms to support wind power development." Renewable Energy 33, 1854-1867

Casier, Liesbeth, Robin Fraser, Mark Halle, and Robert Wolfe. 2013. Shining a Light on Fossil Fuel Subsidies at the WTO: How NGOs Contribute to WTO Notification and Surveillance, ENTWINED Working Paper, 2013-11-04.

Cosbey, Aaron, 2013. Green Industrial Policy and the World Trading System, ENTWINED Issue Brief 17.

Deutsche Bank, 2010. "Global Energy Transfer Feed-in Tariffs for Developing Countries."

Fouquet, Doerte and Thomas B. Johansson. 2008. "European renewable energy policy at crossroadsFocus on electricity support mechanisms.” Energy Policy 36(11), 4079-4092

Grossman, Gene M., 1990. "Promoting New Industrial Activities: A survey of recent arguments and evidence," OECD Economic Studies, 14: 87-125.

Hoekman, Bernard M., and Petros C. Mavroidis. 1996. "Policy Externalities and High-Tech Rivalry, Competition and Multilateral Cooperation beyond the WTO", Leiden Journal of International Law, 9: 273-318.

Horlick, Gary and Peggy Clark. 1994. "The 1994 WTO Subsidies Agreement," World Competition, 17: 41-54.

Horn, Henrik, Giovanni Maggi, and Robert W. Staiger. 2010.” Trade Agreements as Endogenously Incomplete Contracts", American Economic Review, 100: 394-419.

Horn, Henrik, and Petros C. Mavroidis. 2011. "To B(TA) or Not to B(TA)? On the Legality and Desirability of Border Tax Adjustments from a Trade Perspective", The World Economy, 34: 19111937.

Howse, Robert. 2010. "Do the World Trade Organization Disciplines on Domestic Subsidies Make Sense? The Case for Legalizing Some Subsidies", in Kyle W. Bagwell, George A. Bermann, and Petros C. Mavroidis (eds.), Law and Economics of Contingent Protection in International Trade, Cambridge University Press: New York City, NY. pp. 85-102.

IEA. 2012. World Energy Outlook 2012. Paris: International Energy Agency.

International Institute for Sustainable Development, Canadian Environmental Law Association, EcoJustice Canada. 2012. Amicus Curiae Submission before the WTO Panel Canada - Certain Measures Affecting the Renewable Energy Generation Sector (DS412).

Lester, Simon. 2011. "The Problem of Subsidies as a Means of Protectionism: Lessons from the WTO EC-Aircraft Case", Melbourne Journal of International Law, 12: 1-28.

Lipp, Judith. 2007. "Lessons for effective renewable electricity policy from Denmark, Germany and the United Kingdom.” Energy Policy 35 (11), 5481-5495

Mavroidis, Petros C. 2012. "Free Lunches? WTO as Public Good, and the WTO's View of Public Goods", European Journal of International Law, 23: 731-742. 
McDonough, Patrick J. 1993. "Subsidies and Countervailing Measures", in Terence P. Stewart (ed.), The GATT Uruguay Round: A Negotiating History (1986-1992), Kluwer Law: Deventer, the Netherlands and Boston, Mass., pp. 803-1008.

Paemen, Hugo, and Alexandra Bentsch. 1995. From the GATT to the WTO: The European Community in the Uruguay Round, Leuven University Press: Leuven, Belgium.

Pindych, Robert S. 2013. "Climate Change Policy: What do the models tell us?” Journal of Economic Literature, 51(3): 860-872.

Rodrik, Dani. 2004. "Industrial Policies for the Twenty-First Century," John F. Kennedy School of Government, Harvard University.

Rubini, Luca. 2012. “Ain't Wastin' Time No More: Subsidies for Renewable Energy, the SCM Agreement Policy Space and Law Reform.” Journal of International Economic Law, 15(2): 525-579.

2010. The Definition of Subsidy and State Aid: WTO and EC Law in Comparative Perspective, Oxford University Press: Oxford, UK.

Salzman, James, and Mark Wu. 2014. "The Next Generation of Trade and Environment Conflicts The Rise of Green Energy Policy", Northwestern University Law Review, 108:

Stewart, Terence. 1993. "The GATT Uruguay Round, a Negotiating History (1986-1994)", Volume IV: The End Game (Part I), Kluwer International: New York City.

Stern, Nicholas. 2006. Stern Review on the Economics of Climate Change (Chapter 16: Policy Responses for Mitigation). London, UK: Her Majesty’s Treasury, 2006.

2013. "The Structure of Economic Modeling of the Potential Impacts of Climate Change: Grafting Gross Underestimation of Risk onto Already Narrow Science Models", Journal of Economic Literature, 51(3): 838-59.

Sykes, Alan O. 2005. "The Economics of the WTO Rules on Subsidies and Countervailing Measures," in Patrick F.J. Macrory, Arthur E. Appleton, Michael G. Plummer (eds.). The World Trade Organization: Legal, Economic and Political Analysis, volume I, Springer Verlag: New York City, New York.

UNEP. 2011. Towards a Green Economy: Pathways to Sustainable Development and Poverty Eradication. Geneva: United Nations Environment Programme.

Winham, Gilbert R. 1986. International Trade and the Tokyo Round Negotiations, Princeton University Press: Princeton, NJ. 


\section{Author contacts:}

\section{Aaron Cosbey}

International Institute for Sustainable Development

6th Floor, 161 Portage Ave. E.

Winnipeg, MB Canada

V0G 1 Y0

Email: Acosbey@gmail.com

\section{Petros C. Mavroidis}

RSCAS, EUI,

Villa La Fonte

Via delle Fontanelle 10

50014 San Domenico di Fiesole (FI)

Italy

Email: petros.mavroidis@eui.eu 